\section{SOME FRESHWATER BIVALVES OF PUNJAB, HARYANA AND HIMACHAL PRADESH}

\author{
S.K. Battish and Meenu Sharma \\ Department of Zoology, Punjab Agricultural University, Ludhiana, \\ Punjab 141004, India.
}

In numerical dominance Mollusca are second only to Arthropoda living in habitats connected with water. Of the six classes under the phylum two, namely Gastropoda and Bivalvia are restricted to inland water bodies and wetlands. The gastropods of Punjab were reported by the present authors earlier (Battish \& Sharma, 1993) and the bivalves of northern India, Bihar, Punjab, Himachal Pradesh and Chandigarh are presented in this paper.

The inland bivalves contribute to the nation's economy, as these support pearl and button industries. Culturing of Lamellidens marginalis and Lamellidens corrianus is picking up for pearl production. The shell pieces are used in preparation of poultry feed and mosaic tiles. Larvae of Unionidae are known to parasitize fishes.

The literature scan reveals that inland bivalvia of India remain unattended by and large. Benson (1862) was perhaps the first to work on Unio. Blanford $(1866,1867,1870)$ published a series of papers on the Malacology covering bivalve genera Unio and Anodonta from India, Sri Lanka, Burma and Yunnan.

Prashad (1921) published work on the Lamellibranchs from the Indian Museum. The publications of Tonapi (1980) and Rao (1989) also contain useful information on Indian Bivalvia. The bivalve species worked out by us are given in Table 1 .

\section{References}

Battish, S.K. and M. Sharma (1993). Freshwater Gastropods of Punjab, India. Geobios New Reports 12: 197-198.

Benson, W.H. (1862). Description of Indian and Burmese species of the genus Unio. Annals of Magazine of Natural History 10(3): 184195.

Blanfords, W.T. (1866). Contribution to Indian Malacology No. 7. List of species of Unio and Anodonta described as occurring in India, Ceylon and Burma. Journal of the Asiatic Society of Bengal 35(2): 134 155.

Blanford, W.T. (1867). Contributions to Indian Malacology No. 8. List of estuary shells collected in the Irawaddy Delta, in Pegu, with description of new species. Journal of the Asiatic Society of Bengal 36(2): 51-72.
Table 1. List of bivalve species recorded in Punjab, Haryana and Himachal Pradesh.

\begin{tabular}{|c|c|}
\hline Scientific name & Habitat \\
\hline \multicolumn{2}{|l|}{$\underline{\text { Amblemidae }}$} \\
\hline$\overline{\text { Parreysia corrugata (Muller, 1774) }}$ & Harike Pattan, Ferozepur (Punjab) \\
\hline \multicolumn{2}{|l|}{ Corbiculidae } \\
\hline Colbicula arata (Sowerby, 1878) & $\begin{array}{l}\text { Sukhna Lake, Chandigarh (Union } \\
\text { Territory) }\end{array}$ \\
\hline $\begin{array}{l}\text { Colbicula assamensis } \\
\text { (Prashad, 1928) }\end{array}$ & Harike Pattan, Ferozepur (Punjab) \\
\hline $\begin{array}{l}\text { Colbicula striatella } \\
\text { Deshayes, } 1854\end{array}$ & Budha Nullah, Ludhiana (Punjab) \\
\hline \multicolumn{2}{|l|}{ Unionidae } \\
\hline Lamellidens corrianus (Lea, 1834) & Kali Bein, Kapurthala (Punjab) \\
\hline $\begin{array}{l}\text { Lamellidens generosus } \\
\text { (Gould, 1847) }\end{array}$ & Renuka Lake, Nahan (Himachal Pradesh) \\
\hline $\begin{array}{l}\text { Lamellidens jenkinsianus } \\
\text { (Benson, 1862) }\end{array}$ & Renuka Lake, Nahan (Himachal Pradesh) \\
\hline Lamellidens lamellatus (Lea, 1838) & $\begin{array}{l}\text { Kali Bein, Kapurthala (Punjab) Renuka } \\
\text { Lake, Nahan (Himachal Pradesh) }\end{array}$ \\
\hline $\begin{array}{l}\text { Lamellidens marginalis } \\
\text { (Lamarck, 1819) }\end{array}$ & $\begin{array}{l}\text { Kali Bein, Kapurthala (Punjab) Renuka } \\
\text { Lake, Nahan (Himachal Pradesh) }\end{array}$ \\
\hline $\begin{array}{l}\text { Lamellidens scutum } \\
\text { (Sowerby, 1868) }\end{array}$ & $\begin{array}{l}\text { Kali Bein, Kapurthala (Punjab) Sukhna } \\
\text { Lake, Chandigarh (Union Territory) }\end{array}$ \\
\hline
\end{tabular}

Blanford, W.T. (1870). Contributions to Indian Malacology No. 9. Description of new species of Paludomus, Cremnoconchus, Cyclostoma and Helicidae form various parts of India. Journal of the Asiatic Society of Bengal 39(2): 9-25.

Prashad, B. (1921). Notes on Lamellibranchs in the Indian Museum. Records of the Indian Museum 22(2): 241-258.

Rao, S.N.V. (1989). Handbook Freshwater Mollusca of India. Zoological Survey of India, 289pp.

Tonapi, G.T. (1980). Freshwater Animals of India. Oxford and IBH, $341 \mathrm{pp}$. 